\title{
Integrated Multi-Level \\ Assessment of Regional Development Sustainability and Mapping
}

\author{
1Vladimir TIKUNOV and ${ }^{2}$ Iga CHERESHNYA \\ Geographical Faculty, Lomonosov Moscow State University, \\ Leninskie Gory, MSU, 1, Moscow 119991, Russia \\ ${ }^{1}$ vstikunov@yandex.ru, ${ }^{2}$ chereshnya.0@yandex.ru
}

Abstract. This article describes a method for the complex assessment of the sustainable development of territories based on social development, economic development and ecological situation indices. The method allows an analysis of the comprehensive, sustainable development of territories, and at the same time details elements of the problem detected by the successive hierarchical decomposition of the aggregated indices. It takes into account the peculiarities of non-homogeneous regions and those which are difficult to compare. Their evaluation using conventional methods of identification and typology does not produce the most rapid, effective, or objective results. The Russian Federation was used an example to test the methodology. The potential analysis of sustainable development was supplemented with a map created according to the colour triangle method, which allows the balance of components to be visualized at each level analysed. The theoretical principles considered and their practical use helped complete an assessment of the basic parameters of sustainable development in the Russian regions. Based on this, it was possible to form a unified list of criteria which might become the national standard for assessing sustainable development at the local, regional and federal levels, and recommended for practical use in the development and adoption of new regional solutions.

Keywords: sustainable development, index, Russian Federation regions, social development, economic development, environmental stress

\section{Introduction}

The development of practical, measurable integral indicators is an important issue in implementing sustainable development. It is not enough to analyse the separate components, whether social, economic or environmental. These independent components must be coordinated to strengthen the present and future potential of social development. A key role in this process is played by their interaction mechanisms. It is difficult to develop indicators to assess them, because first of all, a range of indicators reflecting the stability or instability of development must be defined. Then different indicators must be linked, and thirdly, the indicators that evaluate all three components must be aligned in a single aggregated indicator.
The development of an evaluation methodology is necessary for targeted programmes to solve regional problems of sustainable development. Such indicators should take into account the specifics of regional economic, social and environmental development. Therefore, development should be carried out visualising the goals of sustainable development and using modern methods, including mathematical, statistical modelling methods (Bakirova 2010). In "Concept of the transition of the Russian Federation to sustainable development" (About the concept ..., 1996) it is said that targets can be expressed in terms of quality of life, level of economic development and environmental well-being. These indicators should reflect a level which ensures the security of Russia's development in economic, social, environmental and other aspects. 


\title{
Integrirana višerazinska procjena održivosti regionalnog razvoja i njegovog kartiranja
}

\author{
1Vladimir TIKUNOV i 2Olga ČEREŠNJA \\ Fakultet za geografiju, Moskovsko državno sveučilište Lomonosova, \\ Leninskie Gory, MSU, 1, Moskva 119991, Rusija \\ 1vstikunov@yandex.ru, ${ }^{2}$ chereshnya.o@yandex.ru
}

Sažetak. Članak opisuje metodu složene procjene održivog razvoja područja na temelju indeksa društvenog razvoja, indeksa gospodarskog razvoja i indeksa ekoloških prilika. Razvijena metoda omogućava opsežno analiziranje održivog razvoja područja te u isto vrijeme daje detalje elemenata problema otkrivene sukcesivnom hijerarhijskom razgradnjom svakog od pokazatelja. Metodologija uzima u obzir specifičnosti nehomogenih i teško usporedivih regija, procjena kojih, upotrebom konvencionalnih metoda identifikacije i tipologije, ne daje najbrže, učinkovite i objektivne rezultate. Potvrda metodologije dobivena je na primjeru Ruske Federacije. Mogućnosti analize održivog razvoja dopunjene su kartom izrađenom po metodi trokuta boja koja omogućava vizualiziranje balansa komponenata na svakoj analiziranoj razini. Razmatrani teorijski principi o njihovoj praktičnoj upotrebi pomogli su u kompletiranju procjena parametara održivog razvoja ruskih regija. Na tom je temelju moguće formirati jedinstveni popis kriterija koji bi mogao postati nacionalna norma za procjenu održivog razvoja na lokalnoj, regionalnoj i federalnoj razini i biti preporučen za praktičnu primjenu u razvoju i prihvaćanju novih regionalnih rješenja.

Ključne riječi: održivi razvoj, indeks, regije Ruske Federacije, društveni razvoj, gospodarski razvoj, okolišni stres

\section{Uvod}

Razvoj praktičnih i mjerljivih integralnih indikatora postao je važan problem u primjeni koncepta održivog razvoja. Za takvu procjenu nije dovoljno analizirati odvojene komponente - društvenu, gospodarsku i okolišnu. Pretpostavlja se da te nezavisne komponente moraju biti međusobno harmonizirano koordinirane i ojačati sadašnji i budući potencijal razvoja društva. Ključnu ulogu u tom procesu igraju mehanizmi njihove interakcije. Poteškoća u razvoju indikatora za njihovu procjenu leži u činjenici da je, ponajprije, nužno definirati raspon indikatora koji će odraziti stabilnost ili nestabilnost razvoja, povezati potom različito usmjerene indikatore, a nakon toga međusobno kombinirati indikatore tako da se $\mathrm{u}$ jednom združenom indikatoru dobije procjena triju komponenti.
Razvoj metodologije procjene nužan je za ciljane programe čije je prihvaćanje povezano s rješavanjem problema održivog razvoja regija. Takvi indikatori moraju biti razvijeni uzimajući u obzir gospodarski, društveni i okolišni razvoj regija. Dakle, njihov razvoj treba provesti vizualizacijom ciljeva održivog razvoja i upotrebom suvremenih metoda, uključujući metode matematike, statistike i modeliranja (Bakirova 2010).

U "Konceptu tranzicije Ruske Federacije na održivi razvoj" (About the concept ..., 1996) piše da se ciljevi mogu izraziti s pomoću kvalitete života, razine gospodarskog razvoja i okolišnog blagostanja. Ti pokazatelji trebaju zrcaliti razinu koja osigurava sigurnost ruskog razvoja u gospodarskom, društvenom, okolišnom i drugim aspektima.

Nezamjenjivost i ekvivalentnost svakoga od triju dijelova održivog razvoja pretpostavlja da samo društvo u 


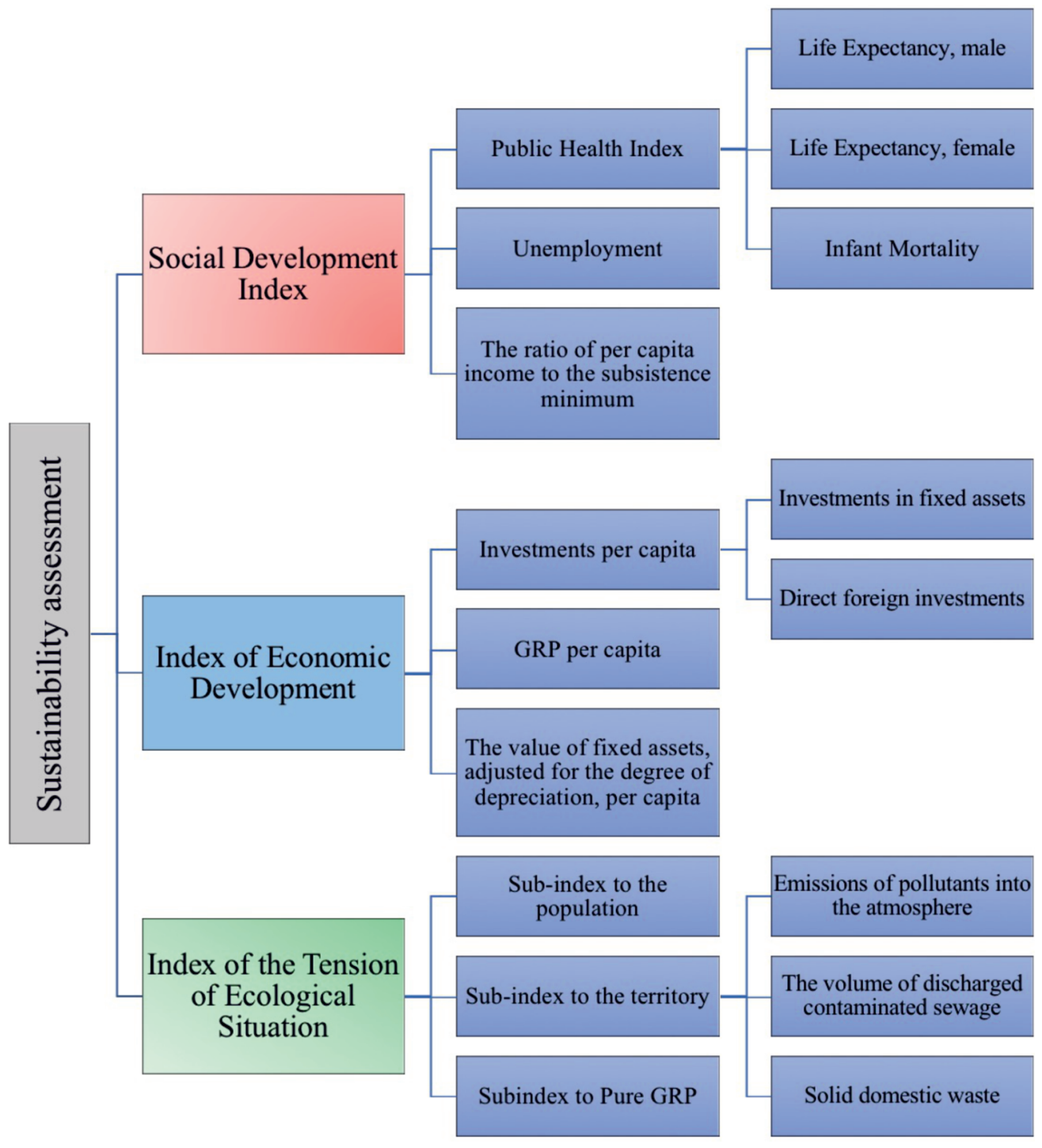

Fig. 1 Scheme for calculating the sustainability of development index

The irreplaceability and equivalence of the three factors of sustainable development assume that only a society in which social, ecological, and economic development are achieved simultaneously can be considered truly sustainable (Vornholz 1994). If even one component is unstable, it affects the stability of society as a whole. Therefore, a stability assessment should be based on an integrated three-component development index, with equal weight for each component.

\section{Materials and Methods}

Proceeding from this principle, a method for the multilevel integrated assessment of sustainability of development was developed based on the group indices of economic development, social development and ecological tensions. The step-by-step process of aggregating all indicators is presented in Figure 1. The group indices are described in detail in other places (Tikunov, Chereshnya 2015, 2016, 2017).

This model of sustainability assessment includes 16 initial indicators and 1,312 measurements (indicatorregion). The sustainability assessment of the regions' development was carried out in relation to ten topics: public health, unemployment, population income, investment attraction, production, production capacity, air pollution, water pollution, solid domestic waste contamination, and the industrial and anthropogenic burdens on the environment.

This approach provides a comprehensive picture of the sustainability of development at various hierarchical levels. The methodology can be used as a standard assessment system for intraregional, interregional and cross-country comparisons, informing the public about the development of the economy, social sphere, quality of the environment and effectiveness of regional 


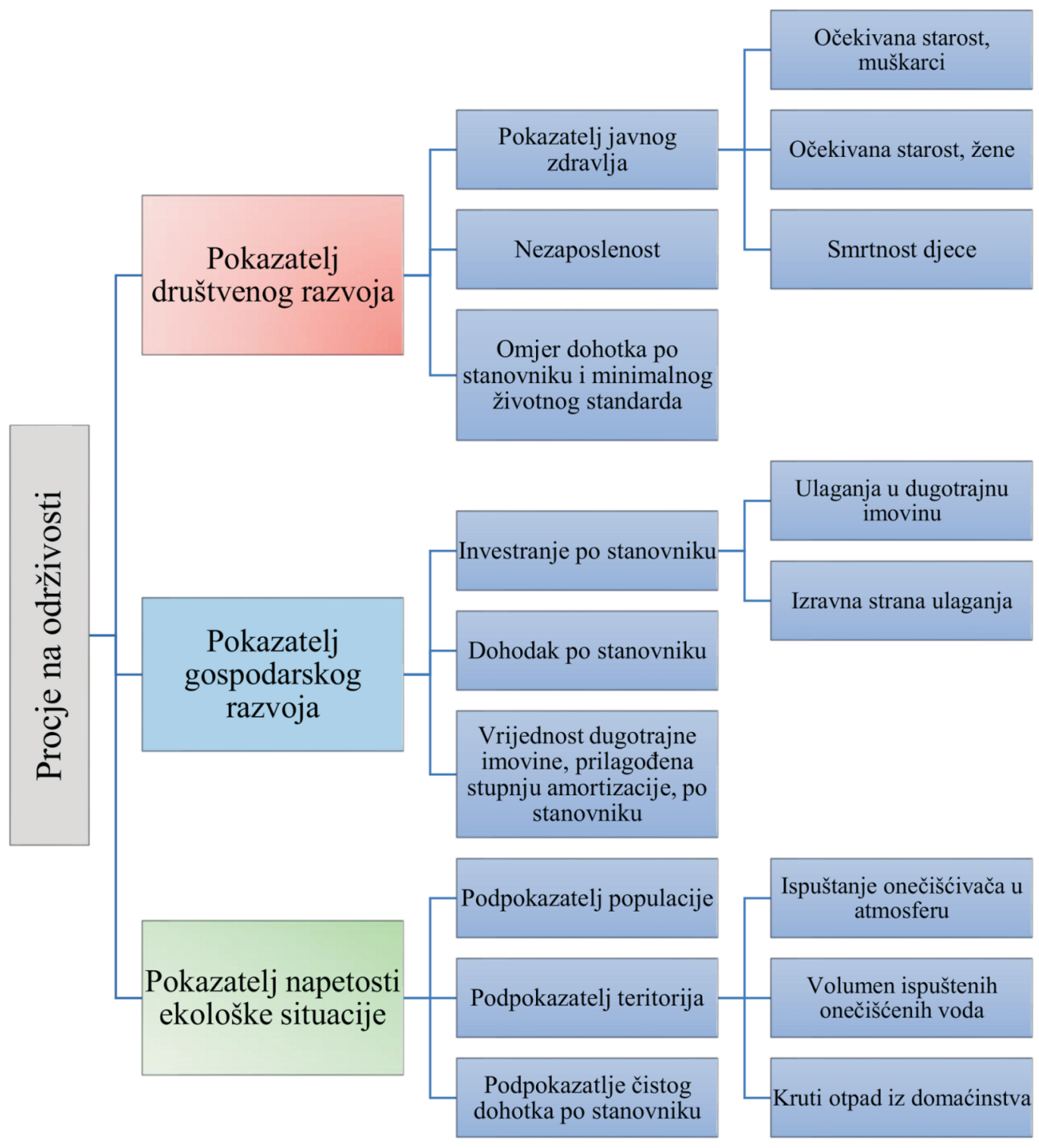

Slika 1. Shema za određivanje indeksa održivog razvoja

kojem se društvena, okolišna i gospodarska održivost razvoja postiže simultano može smatrati stvarno održivim (Vornholz 1994). Nestabilnost samo jedne od komponenti određuje nestabilnost društva kao cjeline. Dakle, procjena stabilnosti treba biti utemeljena na integralnom trokomponentnom indeksu razvoja, s jednakom težinom za svaku komponentu.

\section{Materijali i metode}

Nastavljajući na tom principu, autori su razvili metodologiju višerazinske integrirane procjene održivosti razvoja na temelju grupe pokazatelja gospodarskog razvoja, društvenog razvoja i napetosti ekoloških prilika. Postupak korak-po-korak grupiranja svih pokazatelja prikazan je na slici 1. Grupa pokazatelja opisana je detaljno u drugim radovima autora (Tikunov, Chereshnya 2015, 2016, 2017).
Taj se model procjene održivosti sastoji od 6 potencijalnih indikatora i 1312 mjerenja (indikator-regija). Procjena održivosti razvoja regije izvodi se iz sljedećih deset tema: javno zdravlje, nezaposlenost, prihodi populacije, atraktivnost investiranja, razina proizvodnje, kapacitet proizvodnje, razina onečišćenja zraka, razina onečišćenja vode, stupanj zagađenja krupnim domaćim otpadom, industrijsko i antropogensko opterećenje okoliša.

Takvo široko pokrivanje tema i pokazatelja potvrđuje da taj pristup daje sveuobuhvatnu sliku razvoja održivosti na raznim hijerarhijskim razinama. Ta se metodologija može upotrijebiti kao standardni sustav procjene za usporedbe unutar regija, među regijama i diljem države informirajući javnost o razini razvoja gospodarstva, društva, kvalitete okoliša i učinkovitosti primijenjene regionalne politike. Skup pokazatelja upotrijebljen $\mathrm{u}$ metodologiji sastoji se od javno dostupnih podataka i 


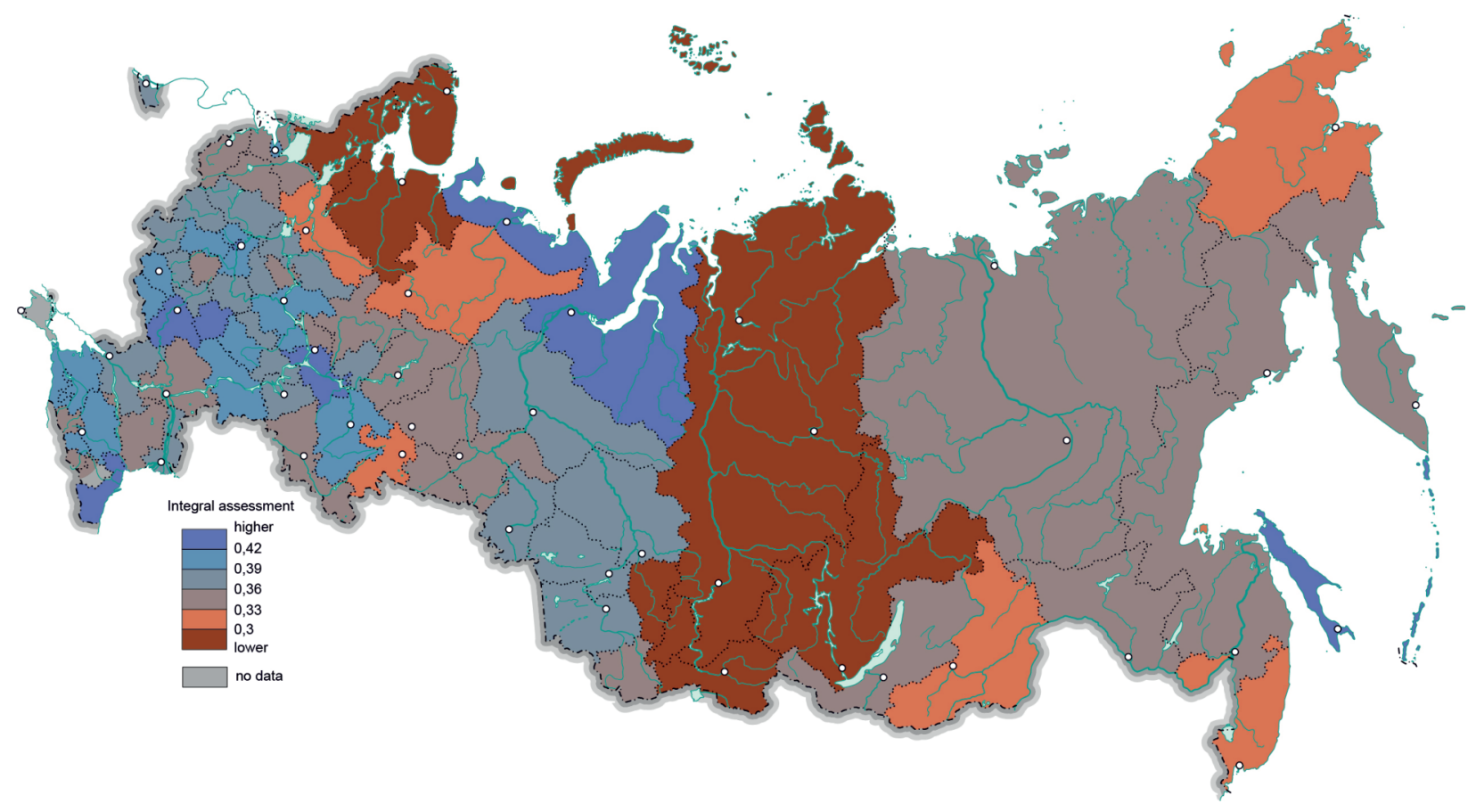

Fig. 2 Map of regional sustainable development rating

Slika 2. Karta koja prikazuje odnos održivog razvoja regija

policies. The set of indicators used consists of publicly available data and enables an assessment of the stability of geographic objects at different time intervals.

The principle of matryoshka (the gradual inclusion of indicators in higher-level indices) provides ample opportunities for analysis at all stages of aggregation of indicators. This approach is complemented by RGB (red, green, blue) visualization maps. The colours show the weight of indicators in the aggregated index, which allows the balance of components to be visualised at each level. The peculiarities of constructing group indices allow us to carry out a three-component analysis of sustainability and assess socio-economic, eco-economic, and eco-social development. The combination of indices is achieved through a unified methodology for normalizing and aggregating initial indicators in integral indices.

\section{Results}

The features of the Russian regions do not allow us to create an objective typology of sustainability. They are characterized by high contrasts regarding most components of sustainable development, and often, the values of different indices in one region may be diametrically opposed. Differences between the regions are deep and enduring (historically and socially conditioned). For example, the correlation between health indicators and income levels in Russia may be negative, but atypical. This is true of Ingushetia and KabardinoBalkaria, for example, where there is high life expectancy and a high index of public health, but at the same time, the lowest index of economic development. Therefore, a rating list was used to display the results of the study, rather than typology (Figure 2). Along with regular visualization, maps with a step-free scale were used to visualize the sustainability rating. Multivariety, shown in the potential parallel use of methods for displaying results, leads to the increased reliability of the final results and allows a better analysis of all the factors that make up a particular phenomenon (Figure 3).

Rating was performed by ranking components of the Russian Federation in descending order according to the value of an integrated three-component development index. This method is much more accurate than ratings that use arithmetic mean scores according to the index of each component. According to some indicators, regions are often ranked unevenly in the scale of values. If a rating is determined by a single indicator, this is insignificant, and the final scale for 82 regions has 82 values. If the rating is based on integrating the results of several intermediate rankings, the step-by-step method begins to distort the picture. Numerical series at intermediate stages must be accounted for - the increased density of values and the gaps between them on some parts of the scale. The methodology for assessing the sustainability of development using a three-component index takes unevenness into account. It 


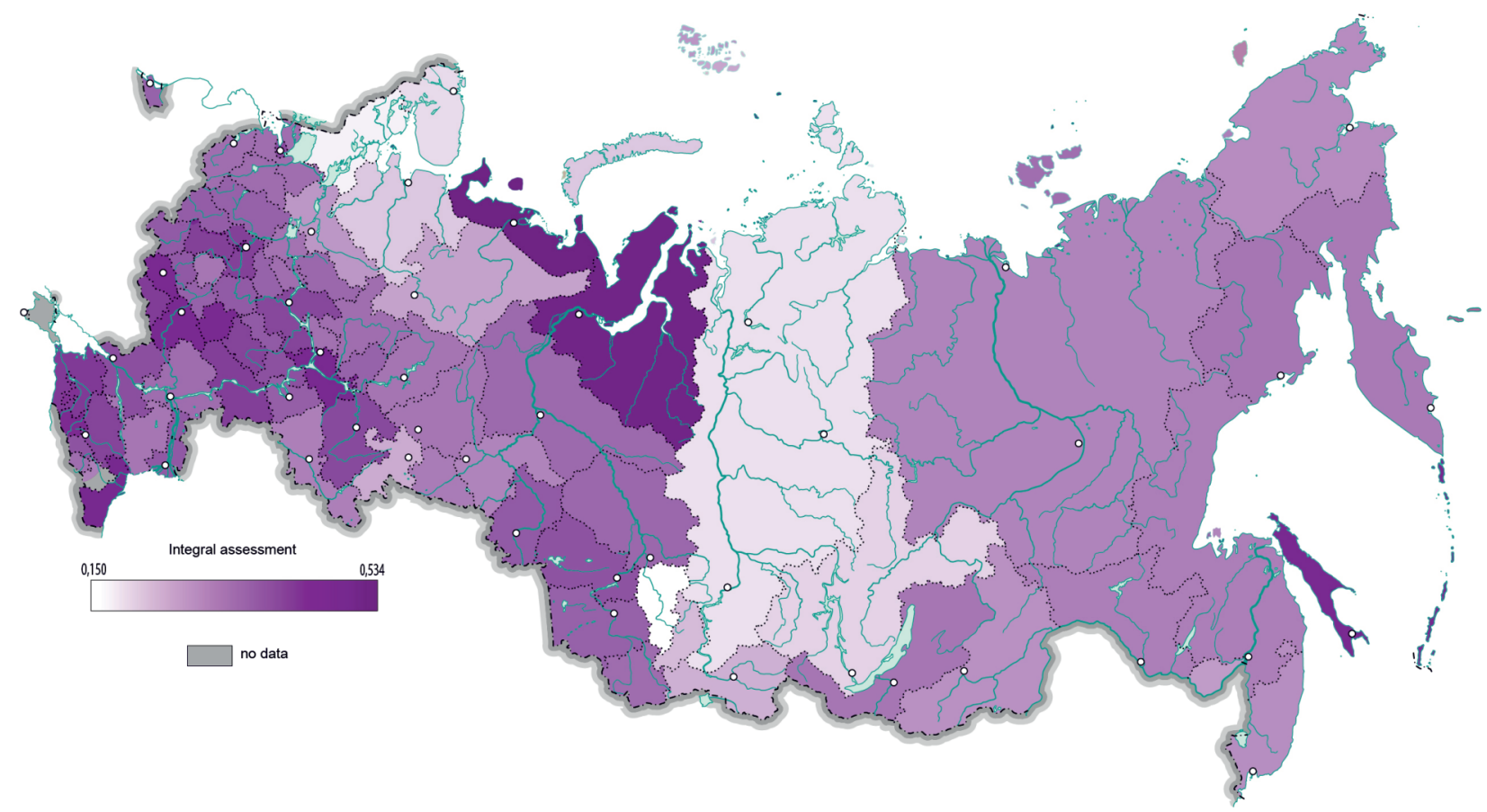

Fig. 3 Map of regional sustainable development of regions in a step-free scale

Slika 3. Karta koja prikazuje odnos održivog razvoja s pomoću neprekidnog mjerila

omogućava procjenu stabilnosti geografskih objekata u različitim vremenskim intervalima.

Princip "matrjoška/babuška" (postupno uključivanje pokazatelja u pokazatelje više razine) daje opsežne mogućnosti za analiziranje na svim fazama grupiranja pokazatelja. Taj je pristup upotpunjen mogućnostima RGB (red, green, blue) karata za vizualizaciju. Boja pokazuje težinu jednog ili drugog pokazatelja u grupnom indeksu, što omogućuje balansiranje komponenti na svakoj razini. Posebnost konstrukcije grupnih pokazatelja omogućava nam ne samo trokomponentnu analizu održivosti, nego i procjenu društveno-gospodarskog, okolišno-gospodarskog i okolišno-društvenog razvoja. Mogućnost kombiniranja pokazatelja postignuta je jedinstvenom metodologijom za normiranje i grupiranje inicijalnih pokazatelja u integrirane pokazatelje.

\section{Rezultati}

Svojstva ruskih regija ne omogućavaju kreiranje objektivne tipologije održivosti. Karakterizira ih veliki kontrast većine komponenata održivog razvoja. Često vrijednosti različitih pokazatelja $u$ jednoj regiji mogu biti dijametralno suprotne onima u drugoj regiji. Razlike između regija su stabilne i duboke (povijesno i društveno uvjetovane). Tako korelacija između pokazatelja zdravlja i razine prihoda u Rusiji može biti negativna, što nije tipično. Takva je slika nastala, primjerice u Inguškoj i Kabardsko-Balkarskoj gdje se očekuje dugovječnost i, u skladu s tim, visok indeks javnog zdravlja, ali je u isto vrijeme najlošiji indeks gospodarskog razvoja. Dakle, da bi se prikazali rezultati studije, upotrijebljena je procjena po stopama, a ne tipologija (slika 2). Osim uobičajene vizualizacije, upotrijebljene su karte s neprekidnim mjerilom za vizualizaciju usporedbe održivosti. Raznolikost, koja se manifestira u mogućnosti paralelene upotrebe metoda prikaza rezultata, vodi na povećanu pouzdanost konačnog rezultata i omogućava bolju analizu cijelog skupa čimbenika koji čine pojedini fenomen (slika 3).

Usporedba je napravljena rangiranjem subjekata Ruske Federacije u silaznom poretku s pomoću vrijednosti skupnog trokomponentnog indeksa razvoja. Ta je metoda mnogo točnija u usporedbi s onom koja upotrebljava aritmetičku sredinu indeksa svake komponente za regiju. Rangiranje po nekom pokazatelju regije je često raspoređeno nepravilno $u$ odnosu na mjerilo vrijednosti. Kad je rangiranje određeno samo jednim pokazateljem, ta nepravilnost nije značajna i konačno mjerilo za 82 regije ima 82 vrijednosti. No kad je rangiranje utemeljeno na integraciji rezultata, takva metoda korak-po-korak počinje deformirati sliku. Nužno je uzeti u obzir strukturu numeričkih nizova u međufazama povećanu gustoću vrijednosti na nekim dijelovima i prazna mjesta na drugima. Metodologija za procjenu održivosti razvoja koja se koristi trokomponentnim indeksom omogućava uzimanje u obzir takve nepravilnosti. Taj pristup uzima u obzir ne samo mjesto svakog 


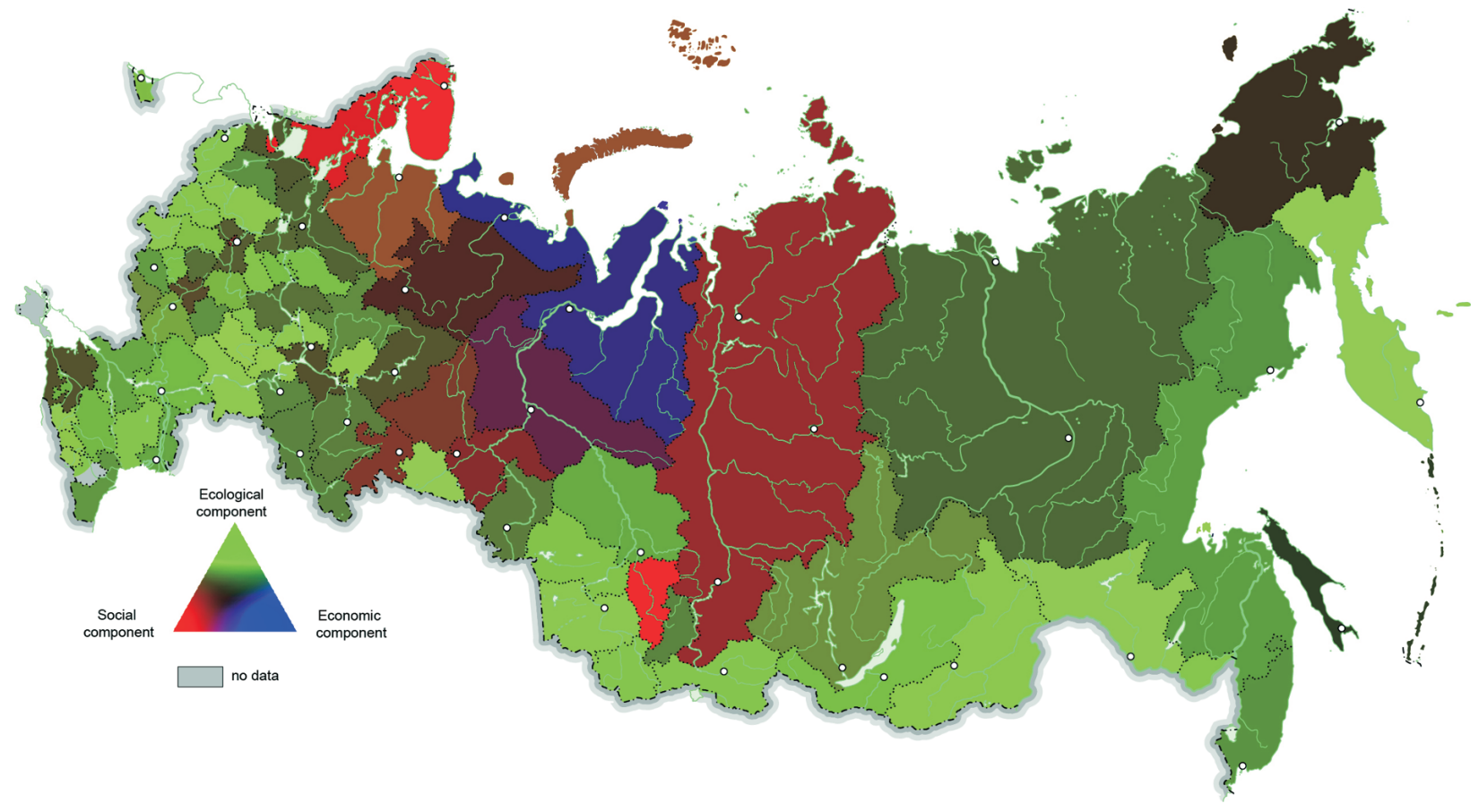

Fig. 4 Visualization using the colour triangle method of the proportional relationship of sustainable development components in the rating

Slika 4. Vizualizacija s pomoću metode trokuta boja proporcionalnih odnosa komponenti održivog razvoja u rangiranju

considers not only the place of each subject in each intermediate index, but also the degree to which it falls behind the best result.

The rating based on the three-component index was led by the rich mining regions: Yamal-Nenets Autonomous District and Nenets Autonomous District. These sparsely populated regions also occupy the third and ninth places according to the social rating. The Nenets Autonomous District, for example, has a huge GRP per capita (RUB 4 252,407.8, comparable to Norway or Qatar) and the highest investment attraction. The main competitive advantage of these regions is their large natural reserves of hydrocarbon raw materials. Hydrocarbon resources are catalysts which accelerate the growth rate of foreign direct investments GRP in these regions. Developed productive strengths and the high profitability of the main branches of economic activity determine a high living standard for the population (by Russian standards), the development of the social sphere, and job provision. The average per capita incomes in the Yamal-Nenets and the Nenets Autonomous Districts are among the highest in the country (RUB 61,252 and RUB 66,491 per month respectively), and the ratio of income to the subsistence minimum is also high (524\% and 463\% respectively, 1.5 times higher than the national average). With their powerful resource potentials, these districts have an undeniable economic development advantage. But their focus on oil and gas extraction implies a strong dependence on foreign market demands. In these regions, significant funds are channelled into environmental activities. However, despite measures taken to protect the environment and protect the flora, fauna and water resources, the ecological situation is fraught with difficulty. Environmental problems affect the health of the population, especially the indigenous peoples. Coupled with severe climate conditions,the average level of public health is 22nd in the Yamal-Nenets Autonomous District and 23rd in the Nenets Autonomous District.

Moscow is in third place. The capital ranks first according to most indicators of social and economic development included in the indices. It is the leader in terms of public health (0.744) and the ratio of per capita income to the subsistence minimum (528\%). It has one of the lowest unemployment rates in the country (0.4\%). It accounts for $21 \%$ of the total GRP of Russia, more than $19 \%$ of the value of fixed assets and more than $13 \%$ of all investment. Moscow is not only the core of the largest agglomeration of the country, but also the capital of Russia, so its capital status development is influenced by agglomeration and institutional factors (Zubarevich 2012). The agglomeration effect allows the best economic results to be achieved due to the territorial concentration of production and labour resources, reducing the costs to businesses and consumers. Its capital status has institutional advantages for development, 
subjekta za svaki posredni indeks, nego također i stupanj zaostajanja za najboljim rezultatom.

Rangiranje na temelju trokomponentnog indeksa izrađeno je za regije bogate rudama - Jamalskonenečki autonomni okrug i Nenečki autonomni okrug. Te slabo naseljene regije nalaze se na vrhu gospodarskog rangiranja na trećem, a prema društvenom rangiranju na devetom mjestu. Nenečki autonomni okrug, na primjer, karakterizira kolosalni dohodak po stanovniku (4 252 407,8 rublja, usporedivo s Norveškom ili Qatarom) i najveća atraktivnost za investiranje. Glavna konkurentna prednost tih regija su velike prirodne rezerve sirovina ugljikovodika. Resursi ugljikovodika su katalizator i akcelerator rasta izravnih investicija iz inozemstva i rasta dohotka u tim regijama. Razvoj proizvodnih snaga i visoka profitabilnost glavnih grana gospodarske aktivnosti određuju vrlo visoku razinu blagostanja populacije (prema ruskim standardima) i razvoj društvene sfere te mogućnost zapošljavanja. Srednja vrijednost prihoda po stanovniku u Jamalskonenečkom autonomnom okrugu i u Nenečkom autonomnom okrugu među najvećima je u zemlji - 61 252, odnosno 66491 rublja na mjesec. Odnos prihoda prema minimalnom životnom vijeku također je velik (524\% i $463 \%, 1,5$ puta veća od nacionalnog prosjeka). Sa snažnim potencijalom $u$ resursima ti okruzi imaju neospornu prednost u gospodarskom razvoju. Međutim, njihovo fokusiranje na vađenje nafte i plina određuje jaku ovisnost gospodarskog blagostanja o prilikama i razini potražnje na stranom tržištu. U tim se regijama značajna sredstva usmjeravaju na okolišne aktivnosti. No unatoč poduzetim mjerama za zaštitu okoliša, zaštitu biljaka, životinja i vodnih resursa, ekološka situacija ostaje teška. Okolišni problemi utječu na zdravlje stanovnika, posebno na zdravlje domaćeg stanovništva. Zajedno s teškim klimatskim uvjetima ti čimbenici određuju prosječnu razinu javnog zdravlja (22. mjesto za Jamalskonemečki autonomni okrug i 23. mjesto za Nenčki autonomni okrug).

Moskva je na trećem mjestu.Rangirana je kao prva za većinu pokazatelja društvenog i gospodarskog razvoja - vodeća u smislu javnog zdravlja $(0,744)$ i odnosu prihoda po stanovniku prema minimalnom životnom vijeku (528\%). No među najmanjima je po nezaposlenosti u zemlji (0,4\%). Računa se da ima $21 \%$ ukupnog prihoda po stanovniku u Rusiji, više od $19 \%$ vrijednosti stalnih sredstava i više od $13 \%$ svih investicija. Moskva nije samo jezgra najveće aglomeracije u zemlji, nego ima i status glavnog grada Rusije, pa je njezin razvoj pod utjecajem dvaju čimbenika: aglomeracijskog i institucijskog (Zubarevich, 2012). Učinak aglomeracije omogućava postizanje najboljih gospodarskih rezultata zbog teritorijalne koncentracije proizvodnje, radnih resursa, smanjenja troškova poslovanja i potrošača. Status glavnoga grada donosi institucijske prednosti za razvoj omogućujući veliku koncentraciju glavnih sjedišta najvećih kompanija, ljudskih resursa i financija. Ukupnost tih čimbenika vodi tako velikim pokazateljima. Osim toga, značajan se dio prihoda ne generira u samom glavnom gradu, nego u regijama u kojima je proizvodnja stvarno smještena. U Moskvi su koncentrirani glavni uredi gotovo svih glavnih ruskih industrijskih poduzeća, kao i predstavnički uredi transnacionalnih kompanija. Visoki položaji svjedoče o stabilnim temeljnim pretpostavkama društveno-ekonomskog razvoja. Prema indeksu napetosti ekološke situacije Moskva stoji na 68. mjestu, što upućuje na nestabilnost okoliša. Naime, Moskva je jedan od najvećih onečišćivača otpadnim vodama (862,9 milijuna m3), a bilježi i najveći iznos emisija iz pokretnih izvora (932,2 tisuća tona).

Na najlošijem mjestu u rangiranju su Kemerovska oblast, Republika Karelija i Krasnojarski kraj. Te se regije nalaze na niskim ili srednjim položajima u rangiranju po svim komponentama. Republika Karelija ima srednju vrijednost gospodarskog razvoja. Regionalni proizvod po stanovniku Karelije je $69 \%$ od ruskog prosjeka, investicijske aktivnosti su 52369 rublja po stanovniku, što je samo $40 \%$ od prosjeka. Prema razini društvenog razvoja Karelija je na 69. mjestu. Odnos prihoda po stanovniku prema minimalnom životnom vijeku je $277 \%$.

Pokazatelj javnog zdravlja u Republici blizak je ruskom prosjeku $(0,51)$. Ekološka situacija u regiji je u najgorem položaju, pa je prema indeksu napetosti ekološke situacije regija jedna od tri najlošije.

Kemerovska oblast je na nešto boljem položaju gospodarskog razvoja u odnosu na Republiku Kareliju, ali gotovo na istoj razini društvenog razvoja. Razina prosječnog prihoda u novcu stanovnika Kemerovske oblasti je 20193 rubalja na mjesec, a odnos prema razini minimalnog životnog vijeka je $294 \%$. U isto vrijeme oblast zauzima posljednje mjesto s obzirom na okolišnu napetost $\mathrm{i}$ jedno od najlošijih mjesta $u$ odnosu na javno zdravlje $(0,45)$. Glavni uzrok leži u vrlo niskom očekivanju trajanja života (61,6 godina za muškarce i 74 godine za žene), što je posljedica velike smrtnosti radno sposobnih muškaraca. Uz ekstremno nepovoljnu ekološku situaciju u Kemerovskoj oblasti, nezdrav život i rasprostranjen alkoholizam, razlozi za povećanu smrtnost muškaraca su i slaba sigurnost na radu i velike nesreće u rudnicima.

Krasnojarski kraj također zauzima jedno od najlošijih mjesta s obzirom na ekološku komponentu. Na 65. je mjestu društvenog razvoja među ruskim regijama. Prihod po stanovniku iznosio je 498372 rubalja. Razina 
providing a high concentration of large company headquarters, human resources and finance. Together, these factors result high indicators. In addition, significant revenues are generated not in the capital itself, but in the regions where production is located. The head offices of almost all major Russian industrial holdings are concentrated in Moscow, along with the representative offices of transnational companies. Its high position is evidence of the stable fundamental prerequisites for socio-economic development. According to the ecological tension index, Moscow is in 68th place, which is an indication of the instability of its surroundings, which have one of the highest rates of wastewater pollution (862.9 million $\mathrm{m} 3$ ) and the highest level of emissions from mobile sources (932.2 thousand tons).

The Kemerovo Region, the Republic of Karelia and the Krasnoyarsk Territory occupy the lowest places in the ranking, with low or medium positions in the ratings for all components. The Republic of Karelia has average values for economic development. The per capita gross regional product is $69 \%$ of the average Russian level, and investment attraction is also low - RUB 52,369 per capita, which is only $40 \%$ of the average. Karelia is in 69th place in terms of social development. The ratio of per capita income to the subsistence minimum is $277 \%$. The public health indicator is close to the average (0.51). The ecological situation is in the worst position, and according to the ecological tension index, the region is in the bottom three.

The Kemerovo region is in a somewhat better position in terms of economic development than the Republic of Karelia, but has almost the same level of social development. The average per capita income is RUB 20,193 per month, and the ratio to the subsistence level is $294 \%$. At the same time, the region occupies last place in terms of environmental tension and one of the lowest places in terms of public health (0.45). The main problem very low life expectancy (61.6 years for men and 74 years for women), which is a consequence of high mortality among men of working age. The extremely unfavourable ecological situation in the region, unhealthy lifestyle and widespread alcoholism contribute to increased male mortality, while poor labour safety and accidents at mines account for many deaths.

The Krasnoyarsk region is also near the bottom in terms of the ecological component. It is in 65th place regarding social development among the regions of Russia. The per capita GRP of the region amounts to RUB 498,372. The level of per capita investment in the region is $83 \%$ of the average (RUB 110,687 per capita). In 2014, one indicator of the crisis was that direct foreign investment in Russia decreased. Investors began to withdraw funds. The Krasnoyarsk and Sverdlovsk regions have the greatest outflow of investments. The average per capita income in the region is RUB 24,806 per month, but purchasing power (298\%) affects its place negatively according to this indicator. The region is characterized by a poor state of public health (0.47) - there is a high incidence of AIDS and tuberculosis, and significant alcoholism. Health is also affected by high environment pollution.

The social, ecological and economic components must be indispensable, equivalent, and achieved simultaneously for a society to be considered sustainable (Vornholz 1994). So in addition to ranking, which is often due to the prevalence of one component, all three components must be analysed together. To visualize the proportional ratio of the social, economic and environmental components of the sustainability index, a map was drawn using the colour triangle technique (RGB) with one colour for each component: social - red, economic - blue, and ecological - green (Figure 4). The same level of development for all three components is shown by mixing these three colours, resulting in grey.

As can be seen on the map, in the overwhelming majority of regions it is difficult to talk about the sustainability of all three components, and this can be interpreted as the imbalance of a significant number of factors that determine the achievements and failures of territories on the path to sustainable development and their strong spatial differentiation. The results indicate developmental disproportion of development between the regions and within each one. There are differences that determine the need to develop and adopt appropriate, effective solutions to the priority problems of sustainable development.

In the Russian context, there are very few regions where there is a development model that provides acceptably high, balanced values for all the main components of sustainability. Such regions include the Sakhalin Oblast, which maintains stable positions in the ratings for environmental and social components, and is one of the leaders in the economic sector. In the Yamal-Nenets Autonomous District, only the ecological component is lagging behind. Other regions show an even balance of social, economic and environmental components, in the sense that they have, equally low indices for all three components (for example, the Republic of Komi). For the rest, the rating is formed due to one or two components, and as can be seen in Figure 3, the ecological component prevails. The weak development of the economic component is caused by the unstable development model of the e Russian economy (export of raw materials) and the resulting disproportion between 
investiranja po stanovniku u regiji je $83 \%$ ruskog prosjeka (110 687 rubalja po stanovniku). U 2014. godini izravna inozemna investiranja u Rusiji su smanjena, što je jedan od pokazatelja krize. Investitori su počeli izvlačiti više sredstava od uloženih. Zajedno sa Sverdlovskom oblasti, Krasnojarski kraj jedna je od regija s najvećim odljevom investicija. Prosjek prihoda po stanovniku u oblasti je 24806 rubalja na mjesec, ali kupovna moć (298\%) snižava njezino mjesto po tom pokazatelju. Oblast karakterizira nepovoljno stanje javnog zdravlja $(0,47)$ - mnogo je slučajeva SIDA-e i tuberkuloze, značajan je i alkoholizam. Na zdravlje stanovnika znatno utječe i veliko onečišćenje okoliša.

Budući da neophodnost i ekvivalentnost društvene, ekološke i gospodarske komponente održivog razvoja pretpostavlja da se društvo može smatrati održivim samo ako se održivost svake od njih postiže istodobno (Vornholz 1994), potrebno je ne samo uzeti u obzir mjesto regije u rangiranju, što je, kako je prikazano, često zbog prevalencije jedne komponente, nego i analizirati ravnotežu svih triju komponenti.

Da bi se vizualizirao proporcionalni omjer društvenih, gospodarskih i ekoloških komponenti indeksa održivosti, izrađena je karta $u$ tehnici trokuta boja (RGB), gdje svaka komponenta ima svoju boju: društvena - crvenu, gospodarska - plavu i ekološka - zelenu (slika 4). Jednaka razina razvoja svih triju komponenti odgovara miješanju jednakih dijelova tih triju boja i daje sivu.

Kao što se može vidjeti na karti, u velikoj većini regija teško je govoriti o održivosti svih triju komponenti, što se može protumačiti kao neravnoteža značajnog broja čimbenika koji određuju postignuća i propuste teritorija na putu održivog razvoja i njihove snažne prostorne diferencijacije. Rezultati ukazuju na nerazmjernost ne samo između regija, nego i unutar svake od njih. U gospodarskim, socijalnim i okolišnim uvjetima regija postoje razlike koje određuju potrebu za razvojem i usvajanjem odgovarajućih učinkovitih rješenja prioritetnih problema njihovog održivog razvoja.

U ruskom kontekstu postoji vrlo malo regija koje imaju model razvoja koji osigurava prihvatljive visoke i uravnotežene vrijednosti svih glavnih komponenti održivosti. Takve regije uključuju Sahalinsku oblast (koja ima stabilan položaj u ocjenama na ekološkoj i društvenoj komponenti te jedno od vodećih mjesta u gospodarskom sektoru) i Jamalskonenečki autonomni okrug (gdje probija samo ekološka komponenta). Ipak, postoje i druge regije s prilično uravnoteženim udjelima društvenih, gospodarskih i ekoloških komponenti.
To su regije s jednako slabim pokazateljima za sve tri komponente (npr. Republika Komi). Očigledno je da je u velikoj većini ostalih regija ocjena formirana zbog jedne ili dviju komponenti, a, kao što se može vidjeti na slici 3, ekološka komponenta prevladava. Slab razvoj gospodarske komponente $u$ regijama uzrokovan je nestabilnim modelom razvoja ruske ekonomije (izvoz sirovina) i rezultirajuće nerazmjernosti među subjektima. Da bi se povećala održivost razvoja, potrebno je usredotočiti gospodarstvo ne na potrošnju prirodnih resursa, već na stvaranje dodane vrijednosti kroz učinkovito korištenje faktora rada i kapitala. Društvena komponenta prevladava u visoko urbaniziranim područjima s lošom ekologijom (Čeljabinska i Kemerovska oblast).

Promatrana "opća nestabilnost" čini nedovoljnu usporedbu ruskih regija samo $s$ vrijednostima integralnog indeksa koji karakterizira stupanj stabilnosti općenito. Distribucija subjekata u konačnoj ocjeni samo je preduvjet daljnje promišljene analize postojećeg sustava upravljanja, uključujući područja zaštite prirode. Taj se pristup najboljim pokazuje tijekom duljeg vremena, što omogućuje praćenje napretka ili regresije prema održivom razvoju.Što je veći stupanj nestabilnosti teritorija, to je vrednije analizirati uzroke nestabilnosti, tj. vrijednosti pojedinačnih komponenti održivog razvoja. Sekvencijalna hijerarhijska razgradnja svakoga od grupiranih pokazatelja temeljenih na nizu RGB karata omogućuje vam da u analizi idete prema skupu početnih statističkih pokazatelja. Kao rezultat te analize, svaka će regija moći prepoznati svoje snage i slabosti i koristiti stečena znanja za svjesno upravljanje održivim razvojem. Taj je pristup osobito nužan za ruske uvjete jer su uvjeti i preduvjeti koji stvaraju promatranu nestabilnost razvoja u različitim regijama radikalno različiti (Rubanov, Tikunov 2009). Procjene regionalnog razvoja, dobivene kao rezultat provedenih eksperimenata, otvaraju velike mogućnosti za tumačenje i analizu rezultata. Prilikom njihova razmatranja valja uzeti u obzir da se izbor pokazatelja i njihova integracija u podindekse temelje prvenstveno na procjeni kvalitete života. Sukladno tome, konačna bi procjena, pored sadašnjih društvenogospodarskih i ekoloških procesa i trendova, prvenstveno trebala odražavati potencijal regije za dug, zdrav i ugodan život stanovništva i mogućnosti održivog razvoja.

\section{Zahvala}

Istraživanje je provedeno uz financijskuj podršku Ministarstva obrazovanja i znanosti Rusije, jedinstveni identifikator projekta je RFMEFI58317X0061. 
components. To increase development sustainability, it is necessary to focus less on the consumption of natural resources, and more on creating added value through the effective use of labour and capital. The social component prevails in some territories, for example, in highly urbanized regions with poor ecology, such as the Chelyabinsk and Kemerovo regions.

The general instability observed means a comparison of Russian regions only according to the values of the integral index characterizing the general degree of stability is inadequate. The distribution of the final rating should prompt further thoughtful analysis of the existing management system, including nature protection. This approach is best adopted over a long period of time, so that progress or regression in terms of sustainable development can be monitored. The higher the degree of instability in a territory, the more valuable the analysis of its causes, that is, the values of individual components of sustainable development. The sequential hierarchical decomposition of each aggregated index based on the RGB card series allows one to move down in the analysis to a set of initial statistical indicators. As a result, each region will be able to identify its strengths and weaknesses and use the knowledge gained for the conscious management of sustainable development. This approach is especially necessary in Russian conditions, since the conditions and prerequisites that generate the instability of development are radically different in different types of regions (Rubanov, Tikunov 2009).

The assessments of regional development obtained as a result of the conducted experiments provide great opportunities for interpretation and analysis. It should be remembered that the selection of indicators and their integration into sub-indices were based primarily on assessments of the quality of life. Accordingly, the final assessment, in addition to current socio-economic and environmental processes and trends, should reflect primarily the regions' potential to provide long, healthy comfortable lives for the population and opportunities for sustainable development.

\section{Acknowledgements}

This research was carried out with the financial support of the Ministry of Education and Science of Russia, the unique identifier of the project RFMEFI58317X0061.

\section{References / Literatura}

About the concept of the Russian Federation transition to sustainable development. Presidential Decree of April 1, 1996, No. 440, Rossiyskaya gazeta, 1996, April 9 (in Russian)

Bakirova A M, Bulanov A Yu, Gervasi M A (2010) The factors of sustainable development of regions of Russia: Monograph / Ed S. Chernoff. Novosibirsk: SIBPRINT, 276 p. (in Russian)

Rubanov I N, Tikunov V S (2009) Sustainable Development of Russian Regions: an integrated assessment. Geographical Bulletin, No. 3, 69-76 (in Russian)

Tikunov V, Chereshnya 0 (2015) Index of Economic Development of the Russian Federation. VestnikMoskov. Univ. Ser. 5. Geography. No. 6, 41-47 (in Russian)

Tikunov V, Chereshnya 0 (2016) Social Development Index of the Russian Federation regions. Math. Russian Academy of Sciences. Ser. Geogr. No. 1, 19-24 (in Russian)

Tikunov V S, Chereshnya 0 Yu (2017) The pollution index and the index of the ecological tension in the regions of the Russian Federation. Theoretical and apply ecology, No. 3, 34-38 (in Russian)

Vornholz G (1994) The sustainable development approach. Intereconomics, Vol. 29, No. 4, 194-198

Zubarevich N V (2012) Rent Metropolitan status. Pro et Contra. Vol. 16, No. 6, 6-18 (in Russian) 